\title{
PENDIDIKAN SEBAGAI AGEN PERUBAHAN MENUJU MASYARAKAT INDONESIA SEUTUHNYA
}

\author{
Ridwan Idris \\ Fakultas Tarbiyah dan Keguruan UIN Alauddin Makassar \\ Kampus II: Jalan Sultan Alauddin Nomor 36 Samata-Gowa \\ Email: ridwanidris11@yahoo.com
}

\begin{abstract}
Abstrak:
Tulisan ini akan membahas tentang perubahan sosial di Indonesia, proses pendidikan di Indonesia, masyarakat Indonesia seutuhnya dan peranan pendidikan sebagai agen perubahan sosial. Saat sekarang ini, pendidikan kita masih jauh untuk dapat dikatakan menjadi agen perubahan. Hal tersebut dikarenakan variatifnya tantangan seperti; masalah mutu pendidikan, relevansi pendidikan, akses pendidikan, manajemen sistem pendidikan nasional, sumber pembiayaan, perbedaan prioritas pengelolaan pendidikan antar-kabupaten/kota sebagai konsekuensi otonomi daerah. Tantangan mesti dihadapi untuk dapat mewujudkan manusia Indonesia yang; religius dan bermoral, menguasai ilmu pengetahuan dan keterampilan, sehat jasmani dan rohani, berkepribadian dan bertanggung jawab. Untuk mewujudkan masyarakat Indonesia seutuhnya, pendidikan harus relevan dengan empat pilar belajar yaitu; learning to know, learning to do, learning to live together, dan learning to be.
\end{abstract}

\begin{abstract}
:
This paper discusses about social change in Indonesia, the process of education in Indonesia, the complete Indonesian people and the role of education as an agent of social change. Nowadays, our education is still far to be called as an agent of change. That is because of the varied challenges such as problems of education quality, relevance of education, access to education, national education system management, financing sources, differences in management priorities inter regency/city as a consequence of regional autonomy. Challenges must be overcome to realize the Indonesian people; which are religious and moral, master of science and skills, have physically and mentally healthy, have good personality and have responsiblity. To realize the complete Indonesian society, education should be relevant to the four pillars of learning, namely: learning to know, learning to do, learning to live together, and learning to be.
\end{abstract}

\section{Kata kunci:}

Pendidikan, agen perubahan, perubahan sosial, masyarakat Indonesia seutuhnya.

INDONESIA telah menjadi bagian dari masyarakat dunia yang terus berkembang. Perkembangan ini mengakibatkan perubahan di semua bidang kehidupan. Perubahan yang sangat pesat dan signifikan telah membawa perubahan sosial yang harus dibarengi dengan adanya transformasi dalam pengetahuan dan perkembangan teknologi. Oleh karenanya, kita tidak bisa menghindar dari sebuah perubahan sosial karena tidak ada suatu masyarakat yang tidak berubah. ${ }^{1}$

Menurut Tilaar, perubahan yang terjadi di masyarakat disebabkan oleh tiga faktor utama, yaitu; kebutuhan akan demokratisasi, kemajuan ilmu pengetahuan dan 
teknologi serta globalisasi. ${ }^{2}$ Pertama, demokratisasi menjadi sangat berpengaruh mengingat masyarakat dunia menjadi masyarakat tanpa sekat yang harus saling berpengaruh dan saling membutuhkan. Kebutuhan akan demokratisasi dilandasi atas kemauan masyarakat untuk mendapat kehidupan yang layak sesuai dengan hak asasi manusia (HAM). Kedua, Kemajuan teknologi telah memberikan pengaruh yang besar terhadap perubahan suatu masyarakat. Kemajuan ini disebabkan oleh kebutuhan umat manusia untuk lebih cepat dalam bertindak dan untuk memudahkan segala kebutuhan manusia yang ada. Selain itu, kemajuan ini didasarkan pada hakikat manusia yang ingin mengetahui segala sesuatu secara lebih mendalam. Ketiga, globalisasi sangat berpengaruh bagi perubahan mengingat hubungan antar manusia akan terasa lebih dekat dan saling bersaing. Masyarakat yang tidak dapat membendung arus globalisasi akan terbawa arus, sedangkan masyarakat yang dapat memanfaatkan arus globalisasi akan mendapatkan keuntungan dari situasi ini.

Perubahan-perubahan ini tentu saja membawa dampak baik yang positif ataupun yang negatif. Oleh karena itu, yang perlu dipikirkan sekarang adalah bagaimana menghadapi perubahan sosial yang ada sehingga dampak yang ditimbulkan tidak mengarah ke sesuatu yang negatif akan tetapi dapat berpengaruh positif.

Pendidikan tentu saja memegang peranan yang sangat penting dalam menghadapi perubahan ini. Pendidikan akan memberikan arah yang jelas tentang bagaimana menyikapi perubahan. Perubahan akan terasa dapat dilalui dengan baik dan dijadikan sebagai landasan dalam mewujudkan pembangunan masyarakat Indonesia seutuhnya apabila pendidikan menjadi pilar utama dalam perubahan itu. Dengan demikian, seharusnya dan sewajarnya perhatian terhadap pendidikan lebih tinggi dengan bidang-bidang lain, karena bidang-bidang yang lain akan berkembang dengan sendirinya jika pendidikan sudah terlebih dahulu baik. Nurcholish Madjid menyarankan bahwa harus ada pemimpin yang memiliki kesadaran yang tinggi terhadap pendidikan sehingga pendidikan betul-betul menjadi agen perubahan bagi masyarakat di tengah-tengah perubahan global dewasa ini. ${ }^{3}$

Indonesia adalah bagian yang tidak terpisahkan dari masyarakat dunia, yang tentu saja akan mengalami pengaruh yang hebat dari demokratisasi, kemajuan ilmu pengetahuan dan teknologi serta globalisasi. Masyarakat Indonesia harus mampu beradaptasi dengan segala bentuk perubahan sosial dunia. Masyarakat dunia dengan segala sistem yang ada harus dikejar dan menjadi tantangan dalam mewujudkan masyarakat Indonesia seutuhnya. Masyarakat yang memiliki jati diri sebagai bangsa Indonesia dan mampu hidup dan berkembang sesuai dengan perkembangan dunia yang ada.

Indonesia pada saat ini dihadapkan pada berbagai macam persoalan, khususnya pasca krisis, di mana masalah politik, ekonomi dan sosial menjadi sebuah persoalan yang pelik untuk diatur. Menurut Tilaar, membina atau membangun masyarakat Indonesia baru bukanlah perkara mudah. Para pakar ilmu politik mengingatkan akan terjadinya suatu masa transisi yang dapat mempengaruhi keutuhan bangsa Indonesia menjadi disintegrasi bangsa apabila tidak dihadapi dengan pendidikan. ${ }^{4}$ 
Melalui praktik pendidikan, peserta didik diajak untuk memahami bagaimana sejarah atau pengalaman budaya dapat ditransformasi dalam zaman kehidupan yang akan mereka alami serta mempersiapkan mereka dalam menghadapi tantangan dan tuntutan yang ada di dalamnya. Dengan demikian, makna pengetahuan dan kebudayaan sering kali dipaksakan untuk dikombinasikan karena adanya pengaruh zaman terhadap pengetahuan jika ditransformasikan.

Esensi dari tujuan pendidikan nasional adalah proses menumbuhkan bentuk budaya keilmuan, sosial, ekonomi, dan politik yang lebih baik dalam perspektif tertentu harus mengacu pada masa depan yang jelas (pembukaan UUD 1945 alenia 4). Melalui kegiatan pendidikan, gambaran tentang masyarakat yang ideal itu dituangkan dalam alam pikiran peserta didik sehingga terjadi proses pembentukan dan perpindahan budaya. Pemikiran ini mengandung makna bahwa pendidikan sebagai tempat pembelajaran manusia memiliki fungsi sosial (agen perubahan di masyarakat). Dengan pendidikan setiap individu akan mengelola dirinya untuk dapat eksis di tengah lingkungan yang sangat bervariasi sehingga akan terjadi koordinasi yang baik bagi lingkungannya. John Dewey mengemukakan bahwa the school has the function also of coordinating within the disposition of each individual the diverse influences of the various social environments into which he enters. 5

Isu mengenai pentingnya pendidikan sebagai agen perubahan masyarakat menjadi sangat penting untuk didiskusikan mengingat pendidikan Indonesia dewasa ini masih kurang diperhatikan. Sudah lebih sepuluh tahun isu reformasi mengemuka yang mengakibatkan perubahan di semua bidang terjadi, namun bidang pendidikan masih belum mendapat perhatian khusus terutama untuk anggaran. Anggaran pendidikan yang ditetapkan 20 persen pada tahun 2006, baru bisa berjalan $100 \%$ pada tahun 2009 dan 2010. Hal ini mengindikasikan keseriusan pemerintah pada pendidikan sebagai pilar utama reformasi dan perubahan di masa depan perlu dipertanyakan. Padahal salah satu faktor penyebab terpuruknya kehidupan politik dan ekonomi adalah diabaikannya pendidikan nasional sebagai wahana untuk menunjang transformasi budaya menuju tegaknya negara kebangsaan yang berperadaban tinggi. ${ }^{6}$

Lebih lanjut Soedijarto mengemukakan bahwa pendidikan yang dilaksanakan sampai sekarang belum dapat berfungsi sebagai wahana transformasi budaya, karena proses pendidikan yang berlangsung di lembaga pendidikan belum merupakan proses pembudayaan berbagai kemampuan, nilai, dan sikap warga masyarakat negara kebangsaan yang merdeka, demokratis dan berkeadilan sosial. ${ }^{7}$

Berdasarkan beberapa pernyataan di atas, maka tulisan ini akan membahas tentang perubahan sosial di Indonesia, proses pendidikan di Indonesia, masyarakat Indonesia seutuhnya dan peranan pendidikan sebagai agen perubahan sosial.

\section{PEMBAHASAN}

\section{Perubahan Sosial di Indonesia}

Sebagaimana yang telah dikemukakan sebelumnya bahwa terdapat kekuatankekuatan yang dapat mempengaruhi adanya perubahan sosial di tengah masyarakat. 
Indonesia sebagai bagian masyarakat dunia juga akan terkena dampaknya. Masyarakat Indonesia dewasa ini sangat bergantung dan terpengaruh oleh kemajuan ilmu pengetahuan dan teknologi terutama teknologi informasi. Sebagaimana bisa disaksikan bahwa pengaruh teknologi sudah merambah sampai ke pelosok-pelosok desa yang dulu merupakan masyarakat yang kurang mendapatkan akses keluar. Teknologi ini dapat dilihat perkembangannya pada seluruh aspek kehidupan masyarakat.

Kemajuan ilmu pengetahuan dan teknologi membawa bangsa Indonesia ke masa transisi yang sangat sulit. Kehidupan politik, ekonomi dan sosial sangat berbarengan dengan kemajuan ilmu pengetahuan dan teknologi. Perubahan ini perlu dihadapi dengan sangat cepat dan tepat sehingga masyarakat kita tidak akan menjadi sasaran negatif dari sebuah teknologi, akan tetapi dapat menjadi pemain untuk mengarahkan ilmu pengetahuan dan teknologi yang ada untuk dimanfaatkan menjadi kekuatan yang dapat membangun masyarakat Indonesia yang lebih baik. Idealnya untuk dapat memberikan arah yang jelas terhadap perubahan ini, pendidikan adalah solusi yang terbaik. Pendidikan harus mampu menjadi penyaring antara kekuatan positif dan negatif dari perkembangan ilmu pengetahuan dan teknologi.

Kemajuan komunikasi dan teknologi informasi menyebabkan dewasa ini para siswa mendapatkan semburan informasi yang amat deras, jauh lebih deras dari yang pernah dialami orangtua mereka. Puluhan ribu halaman dicetak baik dalam wujud buku, majalah atau koran beredar di masyarakat. Banyak TV dipancarkan masingmasing stasiun televisi dengan jam tayang amat panjang. Di balik perubahan yang amat cepat dalam kehidupan bermasyarakat, anehnya, pendidikan sendiri selama ini tidak mengalami perubahan yang berarti. Sekolah dewasa ini sama dengan sekolah masa lampau. Bagaimana keadaan sekolah dan kelas, bagaimana guru mengajar, bagaimana siswa belajar dan bagaimana hubungan di antara warga sekolah sama dengan lima puluh tahun yang lampau. ${ }^{8}$

Perubahan yang dapat kita lihat juga sebagai akibat dari perubahan sosial adalah keinginan banyak pihak untuk membangun otonomi daerah yang terarah. Otonomi daerah ini adalah akibat dari kekuatan-kekuatan yang mempengaruhi perubahan sosial tadi. Pada dasarnya tujuan dari adanya otonomi daerah sangat relevan dengan reformasi yang sedang dibangun masyarakat sekarang ini, akan tetapi dampak negatif yang bisa timbul adalah disintegrasi bangsa apabila tidak diarahkan dengan baik.

Kebijakan otonomi daerah untuk menjawab tuntutan lokal dan desakan kecenderungan arus global perlu diarahkan dan dicermati dengan baik mengingat kondisi masyarakat dan daerah yang beragam dan sangat rentan terhadap perpecahan bangsa. Perubahan sosial, politik dan pembangunan daerah dari model sentralisasi ke desentralisasi, bukanlah perkara yang mudah dalam prosesnya. Perubahan ini memerlukan perubahan sikap dan mental yang baik dari seluruh aparat di dalamnya. Menurut Muchsan terdapat sendi-sendi otonomi yang harus terpenuhi dalam melaksanakan otonomi daerah; 1) pembagian kewenangan (sharing of power), 2) pembagian pendapatan (distribution of income), dan 3) kemandirian atau penguatan daerah (empowering).${ }^{9}$ Oleh karena itu, perlu adanya persiapan yang matang, terencana, seksama, 
bertahap dan berkelanjutan dalam melaksanakan otonomi daerah sebagai bentuk dari perubahan sosial masyarakat Indonesia.

Perubahan sosial yang berdampak pada perilaku keseharian sosial di Indonesia serta adanya otonomi daerah perlu dihadapi dengan pendidikan. Pendidikan harus mampu menjadi agen perubahan yang dapat memberikan perubahan positif terhadap perubahan sosial. Pendidikan harus mampu mengembangkan kreativitas dan pikiran masyarakat guna menemukan sesuatu yang baru dan berguna bagi perbaikan masyarakat. Makin banyak masyarakat yang menampilkan kemampuan kreativitasnya, masyarakat akan kaya dengan perubahan-perubahan. Introduktif hal-hal baru, produk perubahan masyarakat, ke dalam lembaga pendidikan akan memperbesar peluang berkembangnya kreativitas peserta didik. Dengan kata lain, proses pembelajaran yang mengembangkan kreativitas peserta didik dan memproduksi perubahan masyarakat akan lebih memperkaya peran pendidikan dalam upaya perubahan sosial ke arah yang berkualitas. ${ }^{10}$

\section{Pendidikan di Indonesia}

Proses pendidikan itu sendiri sebagai proses sosial-budaya. Proses pendidikan hanya bisa berlangsung dalam interaksi dan kerjasama antar individu, baik secara langsung maupun tidak langsung, dalam kelompok tertentu. Sesuatu yang ditransfer dan atau ditanamkan dalam proses pendidikan adalah norma/nilai sosial-budaya. Norma/nilai sosial-budaya yang ditransfer adalah hasil seleksi, yang dipandang baik dan bermanfaat dari segi moral-keagamaan dalam sektor kehidupan umat manusia. Norma/nilai masa lalu dan masa kini ditanamkan guna melestarikan masyarakat yang baik. Norma/nilai yang dipandang baik untuk masa depan ditransfer guna perubahan masyarakat ke arah dan taraf yang lebih baik.11

Pendidikan yang baik idealnya akan menopang transformasi nilai budaya yang ada ke arah yang lebih baik dan sesuai dengan perkembangan zaman atau mengikuti perkembangan ilmu pengetahuan dan teknologi di tengah masyarakat. Dengan pendidikan yang demikian, harapan akan perbaikan karakter pribadi, bangsa dan budaya nasional akan lebih dekat terwujud. Dengan demikian, perbaikan pendidikan yang berkelanjutan perlu terus dilakukan dengan mengedepankan kemajuan dan keutuhan bangsa.

Terselenggaranya sistem pendidikan yang relevan dan bermutu merupakan faktor penentu keberhasilan kita dalam mencerdaskan kehidupan bangsa dan memajukan kebudayaan nasional. Karena itu, para pendiri Republik menetapkan upaya mencerdaskan kehidupan bangsa sebagai salah satu fungsi penyelenggaraan pemerintah negara Indonesia dan mewajibkan pemerintah menyelenggarakan satu sistem pengajaran nasional. ${ }^{12}$

Mengingat arti penting dari pendidikan, maka perhatian terhadap pendidikan harus terus dilakukan. Proses pendidikan seharusnya menjadi perhatian serius bagi semua pihak terutama pemerintah. Ketersediaan anggaran yang cukup, peningkatan mutu pendidikan, akses pendidikan bagi seluruh masyarakat harus terus diusahakan. Menurut Arismunandar, ada enam tantangan pendidikan Indonesia saat ini yang harus dihadapi. ${ }^{13}$ 
Pertama, belum memadainya mutu pendidikan. Hal ini dapat dilihat dari dua aspek, global dan nasional. Secara global, data yang dikutip dari International Association for The Evaluation of Educational Achievement (IAEEA) menunjukkan dari 27 negara yang diteliti, siswa SD Indonesia berada pada peringkat 26 dalam hal kemampuan membaca. Demikian pula prestasi akademik siswa sekolah menengah yang berada pada peringkat ke 32 di bidang IPA dan 34 di bidang matematika dari 38 negara yang diteliti. Di perguruan tinggi (PT) juga menunjukkan hal yang sama. Hasil penelitian Asiaweek menunjukkan bahwa PT Indonesia hanya menduduki peringkat bawah dari 77 perguruan tinggi di Asia dan Australia. Human Development Index (HDI) yang diterbitkan UNDP menempatkan Indonesia pada peringkat bawah sebagai negara yang rendah indeks pembangunan manusianya.

Secara nasional, terdapat variasi mutu pendidikan antar-provinsi yang menunjukkan adanya ketimpangan mutu antar-provinsi. Kelompok provinsi yang memiliki capaian mutu tertinggi berada pada kawasan barat Indonesia, khususnya pulau Jawa, sedangkan yang memiliki capaian mutu rendah, berada di kawasan timur Indonesia.

Kedua, masalah relevansi pendidikan. Relevansi pendidikan mengacu pada kesesuaian antara kualifikasi lulusan dan kebutuhan pasar kerja. Berbagai data menunjukkan adanya kecenderungan semakin meningkatnya angka pengangguran tenaga terdidik, khususnya dari kelompok sarjana. Selain itu, sekolah kejuruan yang diharapkan menghasilkan tenaga terampil siap kerja belum seluruhnya menunjukkan hasil yang memuaskan.

Ketiga, bersumber pada belum meratanya akses pendidikan khususnya pendidikan sekolah menengah dan perguruan tinggi. Saat ini jumlah siswa yang menempuh pendidikan sekolah menengah masih sangat terbatas dan paling tinggi 50 persen dari anak usia sekolah menengah. Di perguruan tinggi, angka partisipasinya jauh lebih rendah lagi, paling tinggi 20 persen.

Keempat, bersumber dari belum tertatanya manajemen sistem pendidikan nasional. Hal itu ditandai dengan belum menyatunya manajemen pendidikan di mana pengelolaan madrasah dan pendidikan tinggi keagamaan berada di bawah pengelolaan Kementerian Agama sedangkan pendidikan umum berada di bawah Kementerian Pendidikan dan Kebudayaan. Padahal madrasah menggunakan standarisasi akademik, khususnya kurikulum dari Kementerian Pendidikan dan Kebudayaan. Perbedaan bentuk pengelolaan ini berdampak pada tingkat capaian standar minimal layanan pendidikan.

Kelima, bersumber dari terbatasnya sumber pembiayaan. Pembiayaan pendidikan masih merupakan isu besar dalam pengelolaan pendidikan kita. Keberhasilan wakil rakyat menetapkan klausal dalam amandemen UUD 1945 mengenai anggaran pendidikan sebesar 20 persen pada APBN, APBD Provinsi dan APBD kabupaten/kota belum menjamin ketersediaan pendanaan pendidikan. Padahal kebutuhan pembiayaan pendidikan sangat mendesak terutama dalam membiayai pengadaan dan perbaikan sarana dan prasarana pendidikan, buku teks, pengangkatan guru yang masih dibutuhkan, dan sebagainya. Kebutuhan utama pembiayaan lainnya adalah untuk perluasan akses ke jenjang pendidikan menengah dan pendidikan tinggi. 
Keenam, bersumber dari adanya perbedaan prioritas pengelolaan pendidikan antar-kabupaten/kota sebagai konsekuensi otonomi daerah di bidang pendidikan. Kabupaten/kota yang memiliki komitmen tinggi dalam pendidikan, mengalokasikan anggaran lebih banyak untuk pendidikan, sedangkan kabupaten/kota yang memiliki komitmen rendah mengalokasikan anggaran pendidikan yang terbatas. Bagaimanapun masalah ini ikut mempengaruhi target-target mutu, relevansi, efisiensi dan pemerataan pendidikan secara nasional.

Keenam tantangan tersebut harus segera diatasi dengan sebaik-baiknya, sehingga tidak akan menghambat proses pendidikan dan akan secara langsung menghambat tercapainya masyarakat Indonesia seutuhnya. Banyak hal yang bisa dilakukan untuk mencermati masalah-masalah dalam pendidikan. Hal yang paling penting adalah kemauan dari pemerintah harus terus ditekankan, karena pemerintah merupakan penyelenggara pendidikan yang menjadi penentu dalam mewujudkan masyarakat Indonesia seutuhnya.

Perbaikan terus menerus pada pendidikan merupakan keharusan yang sangat mendesak. Ketercapaian pendidikan yang bermutu tidak mungkin tanpa suatu proses yang terencana, terprogram dan terlaksana dengan efisien, efektif dan relevan. Oleh karena itu, anggaran pendidikan harus lebih dari 20 persen dari APBN untuk pengadaan dan memperbaiki fasilitas sekolah, menyediakan sumber-sumber belajar dan lain-lain. Dengan fasilitas yang memadai didukung oleh kesejahteraan guru kemudian guru dapat melaksanakan kurikulum dengan baik, maka pendidikan yang diharapkan dapat betul-betul terwujud. Soedijarto mengemukakan bahwa sekolah dengan kurikulum yang dirancang dan dilaksanakan secara relevan, efisien dan efektif bakal mampu mendukung terlaksananya fungsi pendidikan nasional untuk mencerdaskan kehidupan bangsa dan memajukan kebudayaan nasional. ${ }^{14}$

\section{Masyarakat Indonesia Seutuhnya}

Kebijakan pendidikan yang menekankan pada bimbingan untuk menumbuhkan dan mengembangkan potensi kreatif setiap peserta didik itu jauh lebih berarti bagi upaya memajukan kehidupan masyarakat Indonesia seutuhnya. Masyarakat Indonesia seutuhnya adalah masyarakat yang memiliki nilai keadilan, adil dengan sesama dan dengan alam sekitarnya. Selanjutnya, masyarakat seutuhnya adalah masyarakat yang memiliki moral bersyukur, bersabar dan berikhlas atau dengan kata lain memiliki jiwa spiritual atau kecerdasan spiritual. ${ }^{15}$

Membangun manusia Indonesia seutuhnya berarti membangun manusia yang memiliki kecerdasan, watak dan kepribadian Indonesia. Kecerdasan berarti kecerdasan intelektual, kecerdasan emosional, kecerdasan spiritual. Memiliki watak berarti memiliki watak yang lembut, sopan dan penyayang dan sebagainya. Sedangkan kepribadian artinya memiliki kepribadian pekerja keras, disiplin sesuai dengan kepribadian Indonesia.

Manusia seperti inilah yang akan dibentuk oleh pendidikan. Manusia seutuhnya tertuang dengan jelas dalam tujuan pendidikan Indonesia yaitu mewujudkan manusia Indonesia yang beriman dan bertaqwa terhadap Tuhan Yang Maha Esa dan 
berbudi pekerti luhur, memiliki pengetahuan dan keterampilan, kesehatan jasmani dan rohani, kepribadian yang mantap dan mandiri serta rasa tanggung jawab kemasyarakatan dan kebangsaan.

Kalau dikaji secara mendalam tujuan pendidikan yang selama ini dirumuskan dalam berbagai UU pendidikan nasional, akan terbaca betapa pendidikan nasional diharapkan mampu melahirkan manusia Indonesia yang:

1. Religius dan bermoral

2. Yang menguasai ilmu pengetahuan dan keterampilan

3. Yang sehat jasmani dan rohani

4. Yang berkepribadian dan bertanggung jawab. ${ }^{16}$

Keempat karakteristik di atas menjadi tolak ukur keberhasilan pendidikan. Dengan menjiwai tujuan pendidikan yang membangun manusia Indonesia seutuhnya, maka masyarakat Indonesia akan mampu bertahan pada perubahan sosial saat sekarang ini. Perubahan yang terjadi akibat dari kemajuan ilmu pengetahuan dan teknologi, globalisasi dan demokrasi harus dibarengi dengan pembangunan manusia yang seutuhnya yang memiliki watak, karakter dan kecerdasan. Tanpa hal itu, maka keutuhan Indonesia sebagai suatu bangsa akan terkoyak dan menjadi korban dari perubahan sosial yang terjadi. Dengan demikian, pendidikan harus terus dikedepankan dan diperhatikan sebagai sebuah agen perubahan watak, karakter dan kecerdasan ke arah yang lebih baik.

\section{Peran Pendidikan Menuju Mayarakat Indonesia Seutuhnya}

Proses pendidikan yang berhasil tidak hanya diukur oleh target-target kuantitatif seperti naiknya persentase APK dan APM atau jumlah siswa yang lulus ujian nasional, tetapi proses pendidikan ditentukan oleh kualitas. Rambu-rambu pendidikan yang berkualitas antara lain; sejauh mana perbaikan kurikulum dapat meningkatkan taraf hidup masyarakat sekitarnya dan apakah dengan pendidikan telah melahirkan pengusaha-pengusaha yang dapat membuka lapangan pekerjaan dan sebagainya. ${ }^{17}$

Ada tiga hal yang akan dibangun oleh pendidikan pada masa yang akan datang yaitu; research and development, unpredictable service and the arts. ${ }^{18}$ Kemampuan pertama adalah kemampuan dalam meneliti dan mengembangkan, artinya bahwa masyarakat terdidik tidak hanya sekedar melakukan tugas-tugas rutin yang ada tapi mampu mencari atau menemukan masalah yang terjadi dan mampu untuk memecahkannya. Kedua, kemampuan untuk memberikan pelayanan tak terduga, yaitu memberikan bantuan dengan segera kepada semua individu yang membutuhkan karena di masa yang akan datang manusia akan saling membutuhkan. Ketiga, adanya kemampuan atau rasa seni yang tinggi dalam segala tindakan sehingga tindakan yang dilakukan dapat dinikmati secara batiniah.

Pernyataan Bruner tersebut mengindikasikan bahwa pendidikan harus mampu memberikan manfaat kepada semua orang karena masyarakat dunia sekarang adalah masyarakat tanpa batas di tengah gempuran teknologi informasi dan proses globalisasi. Dengan demikian, masyarakat yang terdidik adalah masyarakat yang mampu hidup bersama-sama dengan manusia yang lain serta alam sekitarnya. Masyarakat 
yang memiliki pengetahuan luas, hubungan yang luas, wawasan yang besar terhadap dunia dan alam sekitarnya. Dari sinilah peran signifikan dari pendidikan.

Pendidikan harus mampu membangun masyarakat pebelajar yang ingin mengetahui semua hal, kemudian mengaplikasikan yang diketahuinya, selanjutnya dengan pengetahuan yang ada dapat hidup bersama-sama dengan semua makhluk dan menjadi manusia yang seutuhnya. Hal tersebut sangat relevan dengan empat pilar belajar yang dikeluarkan UNESCO, yaitu; learning to know, learning to do, learning to live together, dan learning to be. ${ }^{19}$

Learning to know berarti menekankan pada peran pendidikan untuk menumbuhkan keingintahuan masyarakat untuk mencari dan menjadi peneliti pada semua hal, bukan hanya sekedar penyadur dari hasil pengetahuan orang lain, tapi menjadi penemu dari sebuah ilmu pengetahuan dan teknologi. Dalam hal ini, masyarakat diajak untuk belajar dan berpikir. Belajar dan berpikir tentang makna manusia Indonesia seutuhnya sehingga memiliki pengetahuan yang jelas tentang hal tersebut.

Learning to do menekankan pada kemampuan penguasaan bidang tertentu sehingga relevansi pendidikan dapat terwujud. Sebagaimana diketahui bahwa kemajuan iptek dan globalisasi sedang terjadi sekarang ini, dengan demikian membangun masyarakat seutuhnya berarti mewujudkan masyarakat yang menguasai iptek dan mampu bersaing di tengah dunia kerja yang sangat sedikit dan penuh persaingan. Oleh karena itu, dalam hal ini tujuan pendidikan tentang penguasaan iptek dan keterampilan perlu dimanifestaikan.

Learning to live together menekankan pada kemampuan untuk dapat hidup bersama dengan semua makhluk yang ada. Di tengah masyarakat dunia, perbedaan pasti sering dialami, baik karena perbedaan, suku, ras, agama dan lain-lain sangat mempengaruhi kehidupan bermasyarakat. Oleh karena itu, pendidikan sangat berperan untuk menumbuhkan rasa kebersamaan yang ada walaupun dengan berbagai perbedaan. Pendidikan harus menekankan perbedaan sebagai sebuah sumber kebersamaan bukan permusuhan. Dengan berbagai perbedaan kita akan dapat membangun bangsa yang lebih kuat dan maju yang dipersatukan dalam sebuah pendidikan kebangsaan yaitu bangsa Indonesia.

Learning to be menekankan pada kemampuan untuk menjadi manusia seutuhnya. Manusia seutuhnya yang memiliki kepribadian mantap, kemantapan emosional dan intelektual. Learning to be berarti menjadi manusia yang paripurna yang dapat mengaplikasikan tujuan pendidikan yang sudah dijalani. Manusia Indonesia yang beriman dan bertaqwa terhadap Tuhan Yang Maha Esa dan berbudi pekerti luhur, memiliki pengetahuan dan keterampilan, kesehatan jasmani dan rohani, kepribadian yang mantap dan mandiri serta rasa tanggung jawab kemasyarakatan dan kebangsaan, inilah manusia Indonesia yang seutuhnya (be Indonesian).

\section{SIMPULAN}

Kemajuan ilmu pengetahuan dan teknologi, kebutuhan akan demokratisasi dan proses globalisasi membawa perubahan yang besar terhadap masyarakat. Hal ini 
menjadikan istilah perubahan sosial yang masif telah terjadi. Perubahan ini tidak bisa dielakkan karena memang manusia harus terus berubah di tengah perubahan zaman yang ada. Perubahan ini tentu saja menimbulkan dampak yang positif dan negatif, sehingga diperlukan agen yang dapat mengarahkan perubahan itu.

Pendidikan sangat diharapkan untuk menjadi agen perubahan. Pendidikan menjadi satu-satunya alat untuk menjembatani atau menyaring perubahan itu dan mengarahkannya ke arah yang lebih baik. Oleh karena itu, perhatian terhadap pendidikan harus terus dilakukan sehingga perubahan yang ada dapat terorganisir dengan baik.

Mewujudkan pendidikan yang bisa menjadi agen perubahan, memerlukan keseriusan dari semua pihak terutama pemerintah. Peningkatan fasilitas, guru dan lain sebagainya harus menjadi perhatian utama pemerintah dalam pendidikan. Dengan demikian, ketersediaan anggaran sangat diharapkan.

Dengan berbagai perbaikan pendidikan yang terus menerus dapat diyakini bahwa pendidikan sebagai agen perubahan dapat terwujud di kemudian hari. Dengan pendidikan yang bermutu, bangsa Indonesia bukan lagi sekedar penonton dan hanya menjadi konsumen dari sebuah kemajuan Iptek, akan tetapi dapat menjadi pemain yang dapat mempengaruhi arah kemajuan atau perubahan sosial yang ada dan dapat mewujudkan manusia Indonesia seutuhnya.

\section{CATATAN AKHIR}

1. H.A.R. Tilaar, Perubahan Sosial dan Pendidikan: Pengantar Pedagogik Transformatif Untuk Indonesia, Jakarta: PT. Grasindo, 2002, h. 3.

2. Ibid., h. 21.

3. Nurcholis Madjid, Pendidikan Untuk Masyarakat Indonesia Baru: 70 Tahun Prof.Dr. H.A.R. Tilaar, M.Sc. Jakarta: Grasindo, 2002, h. xxvii..

4. H.A.R. Tilaar, 2002, op. cit, h. 70.

5. John Dewey, Democracy and Education, New York: The Macmillan Company, 1961, h. 22.

6. Soedijarto, Landasan dan Arah Pendidikan Nasional Kita, Jakarta: PT Kompas Media Nusantara, 2008, h. 13.

7. Soedijarto, ibid, h. 14-15.

8. Zamroni, Paradigma Pembangunan Pendidikan Nasional Dalam Mewujudkan Peradaban Bangsa, dalam buku Pendidikan Untuk Masyarakat Indonesia Baru: 70 Tahun Prof. Dr. H.A.R. Tilaar, M.Sc. Jakarta: Grasindo, 2002, h. 34.

9. T.A.M. Tilaar, Peran Perguruan Tinggi di Daerah Dalam Otonomi Daerah, dalam buku Pendidikan Untuk Masyarakat Indonesia Baru: 70 Tahun Prof. Dr. H. A. R. Tilaar, M.Sc. Jakarta: Grasindo, 2002, h. 223.

10. Ambo Enre Abdullah, Pendidikan di Era Otonomi Daerah: Gagasan dan Pengalaman, Yogyakarta: Pustaka Timur, 2005, h. 5.

11. Ambo Enre Abdullah, ibid, h. 9.

12. Soedijarto, op.cit., h. 79.

13. Arismunandar, Manajemen Pendidikan: Peluang dan Tantangan, Makassar: Badan Penerbit UNM, 2006, h. 4-6.

14. Soedijarto, op. cit, h. 118. 
15. Suparlan Suhartono, 2007, Filsafat Pendidikan, Yogyakarta: Ar-Ruzz Media, h. 183.

16. Soedijarto, op. cit, h. 118.

17. H.A.R. Tilaar dan Riant Nugroho, Kebijakan Pendidikan: Pengantar Untuk Memahami Kebijakan Pendidikan dan Kebijakan Pendidikan Sebagai Kebijakan Publik, Yogyakarta: Pustaka Pelajar, 2009, h. 182.

18. Jerome S. Bruner, The Relevance of Education, Toronto, Canada, 1973, h. 105.

19. Jacques Delors et.al., Learning: The Treasure Within, The Report to UNESCO of International Commission for The Twenty-First Century, Paris: UNESCO, 1996, h. 85.

\section{DAFTAR PUSTAKA}

Abdullah, Ambo Enre. Pendidikan di Era Otonomi Daerah: Gagasan dan Pengalaman. Yogyakarta: Pustaka Timur, 2005.

Arismunandar. Manajemen Pendidikan: Peluang dan Tantangan. Makassar: Badan Penerbit UNM, 2006.

Bruner, Jerome S. The Relevance of Education. Toronto, Canada, 1973.

Delors, Jacques, et al. Learning: The Treasure Within, The Report to UNESCO of International Commission for The Twenty-First Century, Paris: UNESCO, 1996.

Dewey, John. Democracy and Education. New York: The Macmillan Company, 1964.

Madjid, Nurcholis. Pendidikan Untuk Masyarakat Indonesia Baru: 70 Tahun Prof.Dr. H.A.R. Tilaar, M.Sc. Jakarta: Grasindo, 2002.

Rosyada, Dede. Paradigma Pendidikan Demokratis. Jakarta: Kencana, 2007.

Soedijarto. Landasan dan Arah Pendidikan Nasional Kita. Jakarta: PT Kompas Media Nusantara. 2008.

Suhartono, Suparlan. Filsafat Pendidikan. Yogyakarta: Ar-Ruzz Media, 2007.

Tilaar, H.A.R. Perubahan Sosial dan Pendidikan: Pengantar Pedagogik Transformatif Untuk Indonesia. Jakarta: PT. Grasindo, 2002.

Tilaar, H.A.R. dan Riant Nugroho. Kebijakan Pendidikan: Pengantar Untuk Memahami Kebijakan Pendidikan dan Kebijakan Pendidikan Sebagai Kebijakan Publik. Yogyakarta: Pustaka Pelajar, 2009.

Tilaar, T.A.M. "Peran Perguruan Tinggi di Daerah dalam Otonomi Daerah," dalam buku Pendidikan untuk Masyarakat Indonesia Baru: 70 Tahun Prof. Dr. H.A.R. Tilaar, M.Sc. Jakarta: Grasindo, 2002.

Zamroni. Paradigma Pembangunan Pendidikan Nasional dalam Mewujudkan Peradaban Bangsa, dalam buku Pendidikan Untuk Masyarakat Indonesia Baru: 70 Tahun Prof. Dr. H.A.R. Tilaar, M.Sc. Jakarta: Grasindo, 2002. 